$\mathrm{Nr} 8$

WARSZAWA-KRAKÓW 2006

Maciej HuCUlaK

Uniwersytet Jagielloński, Kraków

\title{
Procesy współkształtujące globalizację przemysłu piwowarskiego Europy
}

Przemysł piwowarski jest jedną z branż przemysłu przetwórczego, na przykładzie której w wyjątkowo jasny sposób widać przekształcenia związane z szeroko pojmowanymi procesami globalizacji: od przekształceń własnościowych, przez koncentrację produkcji, do przekształceń funkcjonowania i przemian struktury przedsiębiorstw piwowarskich.

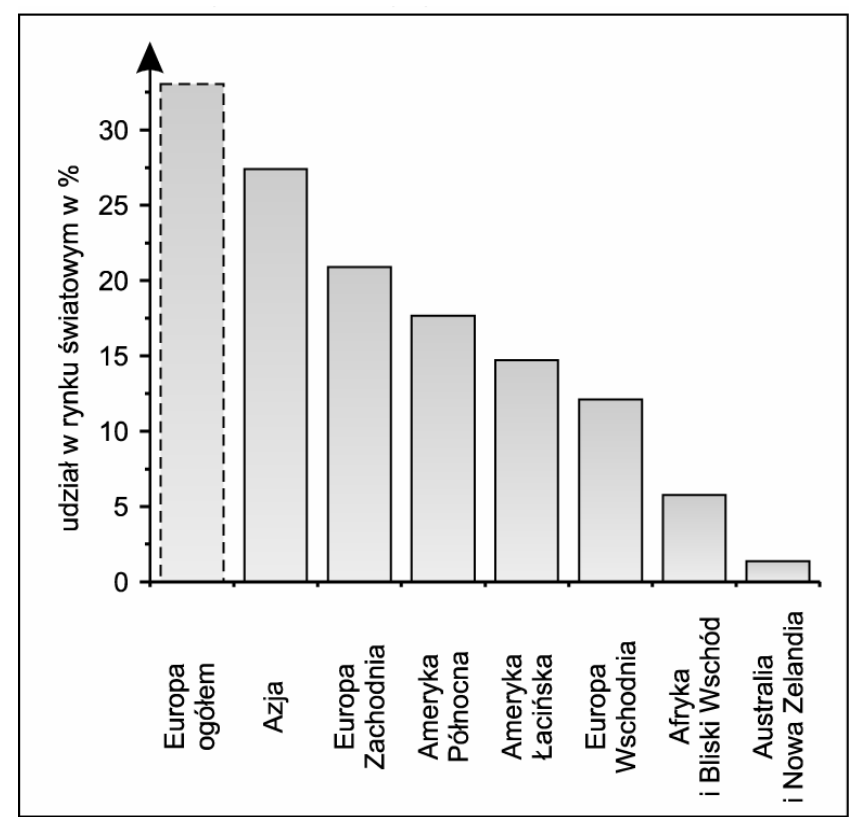

Ryc. 1. Światowy rynek piwa w $2002 \mathrm{r}$.

Źródło: opracowanie własne na podstawie danych Euromonitor International

Wybór kontynentu, na którym chciałem skupić swoją uwagę, nie jest przypadkowy. Europa jest przestrzenią dla przemysłu piwowarskiego pod wieloma względami wyjątkową. Z historycznego punktu widzenia to właśnie ona jest kolebką współczesnego piwowarstwa, a w chwili obecnej skupia zarówno większość produkcji jak i konsumpcji piwa (ryc. 1). Zejście na niższy poziom analizy przestrzennej pozwala zauważyć, że nie jest ona tak jednorodnym regionem, za jaki postronny obserwator mógłby ją uważać. Doskonale pokazują 
to tendencje spożycia piwa w skali globalnej dla lat 1997-2002 (ryc. 2). Wyraźnie odczytać można zasadniczą różnicę między przebiegiem omawianych tendencji dla Europy Zachodniej, w której spożycie piwa wykazuje trend spadkowy, oraz Europy Wschodniej, gdzie przeciwnie - spożycie piwa wzrasta i to w tempie nie mającym swojego odpowiednika skali całego świata (ryc. 2).

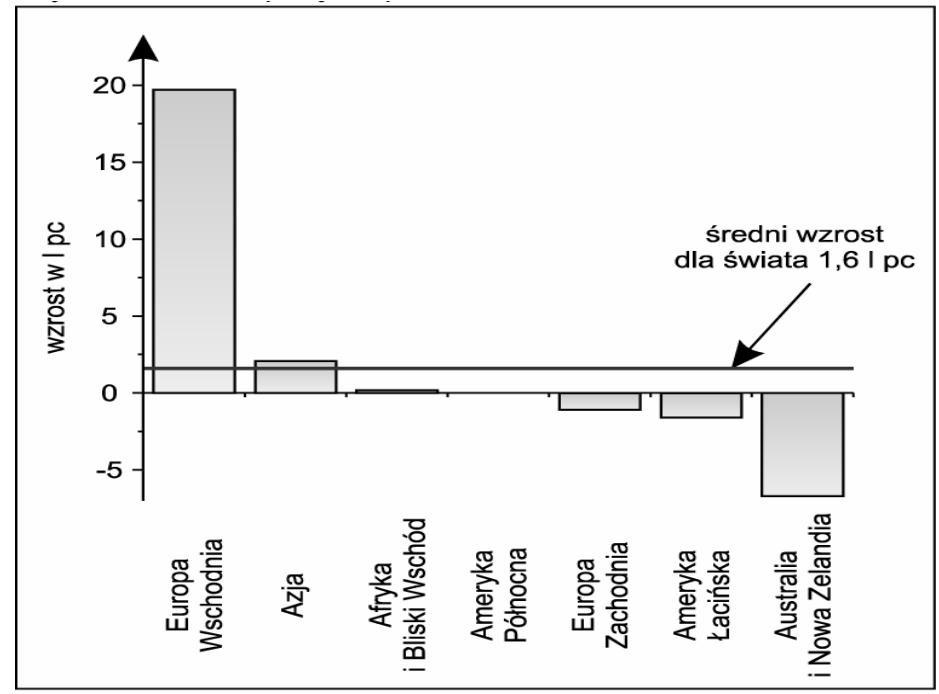

Ryc. 2. Wzrost spożycia piwa na świecie w latach 1997-2002

Źródło: opracowanie własne na podstawie danych Euromonitor International

\section{EGZOGENICZNE I ENDOGENICZNE UWARUNKOWANIA GLOBALIZACJI PRZEMYSŁU PIWOWARSKIEGO}

Piwo jako produkt posiada kilka istotnych cech charakterystycznych, które oddziałują poprzez ograniczanie bądź wręcz przeciwnie ułatwianie przedsiębiorstwom piwowarskim ściśle określonych zachowań przestrzennych. Należą do nich:

- stosunkowo łatwy, na tle pozostałych gałęzi przemysłu napojów alkoholowych, branding, a więc możliwość kreowania rozpoznawalnej marki, potwierdzeniem tego jest chociażby Browar Bass, który jako pierwszy w Anglii zastrzegł swój znak towarowy (czerwony trójkąt) korzystając z wydanego w 1875 r. Trade Mark Registration Act (Lopez 2003),

- niska wartość dodana piwa jako wyrobu, która sprawia, że szczególnie atrakcyjną ścieżką powiększania zysku jest poszukiwanie korzyści wynikających ze skali produkcji,

- stosunkowo wysokie koszty dystrybucji, które powodują istnienie w skali kontynentu barier przestrzennych.

Cechy piwa w nie budzący wątpliwości sposób wpłynęły na rozwój piwowarstwa europejskiego w drugiej połowie ubiegłego wieku. Jednak należy zauważyć, że gwałtowny 
charakter zachodzących obecnie przemian jest w równym stopniu wynikiem cech etapu rozwoju, na którym znalazły się wielkie przedsiębiorstwa branży piwowarskiej u progu transformacji systemowej, przed którą stanęła znacząca część Europy na początku lat 90., a więc inaczej rzecz ujmując, timingu. Do najważniejszych dziedzin, które w interesującym mnie okresie były na odpowiednim poziomie, aby zainicjować dalsze zmiany, należą:

- postęp w logistyce i transporcie - już od początku lat 70. międzynarodowe koncerny działające w branży alkoholowej zaczęły tworzyć scentralizowane systemy magazynowo-składowe,

- postęp w technologii produkcji piwa, polegający w głównej mierze na przedłużeniu trwałości produktu,

- rozwój marketingu, prowadzący do uzyskania przez producentów możliwości kreowania wzorców konsumpcji alkoholu (Lopez 2003).

\section{MIĘDZYNARODOWE KORPORACJE PIWOWARSKIE W EUROPIE}

O roli Europy w światowym przemyśle piwowarskim świadczy również fakt, że spośród 10 największych koncernów, połowa ma swoje główne siedziby w Europie, m.in. południowoafrykański koncern South African Breweries (SAB) przeniósł w roku 1999 swoją główną siedzibę z Johannesburga do Londynu (ryc. 3). W roku 2000 na wspomnianą ,piątkę" przypadało blisko 1/4 całej światowej produkcji. W samej Europie lokowała ona niewiele ponad połowę swojej produkcji, stanowiącej $13 \%$ produkcji światowej, co niewątpliwie jest wynikiem rosnącego zaangażowania europejskich koncernów piwowarskich na innych kontynentach, a w konsekwencji w wymiarze przestrzennym świadczy już nie tylko o postępującej internacjonalizacji, lecz globalizacji.

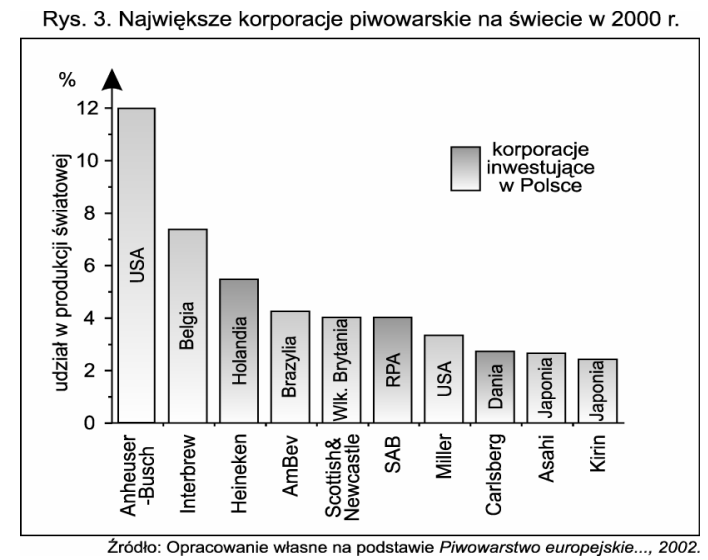

Ryc. 3. Największe korporacje piwowarskie na świecie w $2000 \mathrm{r}$.

Źródło: opracowanie własne na podstawie Piwowarstwo europejskie..., 2002 
Pierwsze oznaki procesów internacjonalizacji europejskiego przemysłu piwowarskiego można dostrzec już pod koniec lat 60., np. przejęcie belgijskiego browaru Maes przez brytyjską grupę Watney-Mann (przejętą w latach 70. przez amerykańskiego potentata na rynku napojów alkoholowych Grand Metropolita) czy utworzenie wspólnego z kapitałem tureckim przedsięwzięcia pod nazwa Türk Tuborg przez Carlsberga (1967). Lata 60. to jednak w piwowarstwie europejskim przede wszystkim konsolidacja wewnętrzna, w ramach poszczególnych państw, czego klasycznym już przykładem fuzja Heinekena $\mathrm{z}$ Amstelem $\mathrm{z}$ roku 1968. Internacjonalizacja nabrała tempa w latach 70 . i na początku lat 80 ., czego przykładem mogą być przejęcia dokonane przez Heinekena i Carlsberga we Włoszech czy Kronenbourga w Belgii. W 1974 roku Heineken zakupił browar Dreher we Włoszech, na przełomie lat 70. i 80. Carlsberg zainwestował również we Włoszech w Birra Poretti, zaś w 1979 roku Brasseries Kronenbourg przejęły belgijski browar Alken.

W pierwszej połowie lat 80 . w związku z narastającym kryzysem gospodarczym natężenie procesu internacjonalizacji osłabło, lecz wraz z pierwszymi oznakami poprawy sytua-cji gospodarczej rozpoczęła się kolejna fala przejęć. Heineken wkroczył na rynek hiszpański poprzez zakup browaru El Aguilla (1984), zaś Brasseries Kronenbourg przejął browar Maes w Belgii (1989).

\section{DYWESYFIKACJA}

Z okresem kryzysu lat 80 . wiąże się szczytowy moment nasilenia niezwykle ciekawego zjawiska dywersyfikacji produkcji przez koncerny piwowarskie, charakterystycznego zresztą wówczas dla całego przemysłu napojów alkoholowych. W skrajnym przypadku, jakim jest Allied Breweries (obecnie Allied Domeq), doprowadziło to do zarzucenia pierwotnie dominującej produkcji piwa i koncentracji na innych rodzajach działalności, jakkolwiek związanych z przemysłem napojów alkoholowych (Lopez 2003). Przykłady prób dywersyfikacji produkcji dla wybranych przedsiębiorstw z branży piwowarskiej przedstawia tab. 1. Co ciekawe, duża część ekonomistów traktuje procesy internacjonalizacji oraz globalizacji w wymiarze przestrzennym jako specyficzny przypadek dywersyfikacji (,dywersyfikację geograficzną"), m.in. Pearce R.D. (1993).

Warto w tym miejscu zwrócić uwagę na istotną kwestię. Otóż zdecydowana większość wymienionych firm już od początku lat 90. zaczęła wycofywać się z części nowo podjętej działalności, skupiając swą uwagę, notabene z powodzeniem, na branży alkoholowej. Proces ten odbywał się niejako w przeciwieństwie do innych przedsiębiorstw z branży alkoholowej, których próby rozszerzenia działalności w ramach samej tylko branży alkoholowej, np. o produkcję piwa, prowadziły w najlepszym wypadku do umiarkowanego powodzenia (Lopez 2003).

Prowadzi to wniosku, że przedsiębiorstwa piwowarskie posiadają najwyższy w branży alkoholowej potencjał adaptacyjny. Wydaje się, że jest to wynikiem zgromadzenia przez nie najwyższego kapitału wiedzy w kluczowych obecnie dla wszystkich działających w branży alkoholowej firm dziedzinach, takich jak: marketing, ze szczególnym uwzględnieniem zarządzania marką (brand management), oraz dystrybucja i logistyka. Postęp w tych dziedzinach 
był zaś wynikiem konieczności przezwyciężania immanentnych ograniczeń tkwiących w piwie jako wyrobie, co można by było określić mianem efektu wysokiej poprzeczki. Tak więc paradoksalnie ograniczenia te sprawiły, że firmy piwowarskie zdolne są do tak skrajnej formy adaptacji, jak ta, w której przedsiębiorstwo jest w stanie zdywersyfikować swoją produkcję wraz z zarzuceniem pierwotnie dominującej działalności i kontynuować z sukcesem nowo podjętą działalność. Adaptację taką, połączoną $\mathrm{z}$ definitywnym zakończeniem w pewnym momencie działalności pierwotnej, należałoby zdaniem autora nazwać adaptacją terminalną in situ.

Tabela 1. Przykłady dywersyfikacji produkcji w wybranych przedsiębiorstwach piwowarskich w Europie

\begin{tabular}{|c|c|c|}
\hline Nazwa browaru & Nowe formy działalności & Rodzaj działalności \\
\hline \multirow{3}{*}{ Bass } & Holiday Inns International & hotelarstwo \\
\hline & Coral Social Clubs & rozrywka \\
\hline & British American Bingo Inc. & rozrywka \\
\hline \multirow{2}{*}{ Whitbread } & Beefeater Steak Houses & restauracje \\
\hline & j. v. z Pepsi-Co - Pizza Hut & restauracje \\
\hline Guinness & United Distilleries* & przemysł spirytusowy \\
\hline Carslberg & $\begin{array}{l}\text { Royal Copenhagen \& Kastrup- } \\
\text {-Holmegaard Glasvaerker A/S } \\
\end{array}$ & produkcja wyrobów ze szkła \\
\hline \begin{tabular}{|l|} 
Heineken \\
\end{tabular} & Bohma** & przemysł spirytusowy \\
\hline Allied Breweries & J. Lyons \& Co.*** & $\begin{array}{l}\text { przemysł spożywczy, } \\
\text { hotelarstwo }\end{array}$ \\
\hline
\end{tabular}

* Firma powstała na bazie przejętych przez Guinessa: Distillers Company Limited oraz Arthur Bell \& Sons posiadająca w swoim portfolio takie marki, jak: Johnnie Walker, Gordon's, Bell's czy Dewar's.

** Producent jednego z najbardziej popularnych ginów w Holandii.

*** Główny udziałowiec m.in. w: J. Lyons Catering Ltd, Embassy Hotels i Lyons Brooke Bond (sieć hoteli w Zambii i Zimbabwe), Baskin \& Robbins - (lody), Tetley Inc. (kawa, herbata i mrożonki), DCA Foods (płatki śniadaniowe), Donut Corp. (słodycze).

Źródło: opracowanie własne na podstawie Lopez 2003 i in.

\section{KONSOLIDACJA}

Wraz z początkiem przemian systemowych w krajach postsocjalistycznych, procesy globalizacji w przemyśle piwowarskim zaczęły nabierać coraz szybszego tempa. Penetracja nowych rynków odbywała się systematycznie, choć powoli, jednak już od połowy lat 90. przejęcia całych grup piwowarskich w Europie Środkowo-Wschodniej stały się coraz bardziej powszechne. Proces konsolidacji nie dotyczy jednak tylko państw postsocjalistycznych, występuje również na największych rynkach Europy Zachodniej, m.in. Wielkiej Brytanii, Hiszpanii, a nawet w konserwatywnych Niemczech czy Belgii. Skala przekształceń jest doprawdy imponująca, co zgodnym chórem potwierdzają analitycy piwnego rynku. Zdaniem Deutsche Bank konsolidacja na rynku piwowarskim zachodzi obecnie najgwałtowniej w dziejach piwowarstwa. W samych tylko latach 1999-2000 łączna wartość wszystkich przejęć w przemyśle piwowarskim sięgnęła 13 mld USD (!) (Cosh, Guest 2001). 
Szybkość zachodzących zmian jest wyjątkowa, nawet jeśli rozpatrzymy sytuację przemysłu piwowarskiego w kontekście całego przemysłu przetwórczego. Znamiennym jest fakt, ze autor niniejszego opracowania natrafił na spory problem, chcąc zilustrować europejski rynek piwa oraz jego największych graczy. Przyjęcie roku 2000 jako przekroju czasowego analizy nie budziłoby większych wattpliwości w innych dziedzinach, jednak gwałtowność zmian w przemyśle piwowarskim wymaga stałej aktualizacji danych, co utrudnia wybór adekwatnego przekroju czasowego nawet przy zadowalającej dostępności danych. Od roku 2000 poczynając, każdy następny rok przynosi bowiem kolejno znaczące zmiany:

- 2000-2001 - wstrzymanie planowanego przejęcia brytyjskiego browaru Bass Plc przez belgijski koncern Interbrew (powstały przez połączenie się w 1987 r. dwóch belgijskich browarów - Artois i Piedbeouf) w wyniku działania angielskich procedur antymonopolowych, wartość planowanej transakcji 2,3 mld $£$,

- 2001-2002 odkupienie części Bass Plc związanej z marką Carling od Interbrew przez amerykański koncern piwowarski Adolph Coors Co. (oficjalne podpisanie umowy sprzedaży nastapiło 2 II 2002 r.) za 1,7 mld USD i w konsekwencji wejście nowego dużego gracza na rynek europejski (nowo powstała firma - Coors Brewers Ltd. została właścicielem m. in. marek: Carling, Worthington, Caffrey's Irish Ale).

- 2001 r. połączenie się duńskiego Carlsberga z norweskim konglomeratem Orkla (1,25 mld USD),

- 2001 r. - Interbrew nabył Breuerei Beck’s \& Co. za kwotę 1,8 mld €,

- 2002 r. połączenie się South African Breweries z amerykańskim Millerem w rezultacie największej fuzji w przemyśle piwowarskim, której wartość szacowana jest na 5 mld USD,

- 2002 r. - pojawienie w pierwszej „dziesiątce” tureckiego koncernu piwowarskiego Efes Beverage Group (EBG).

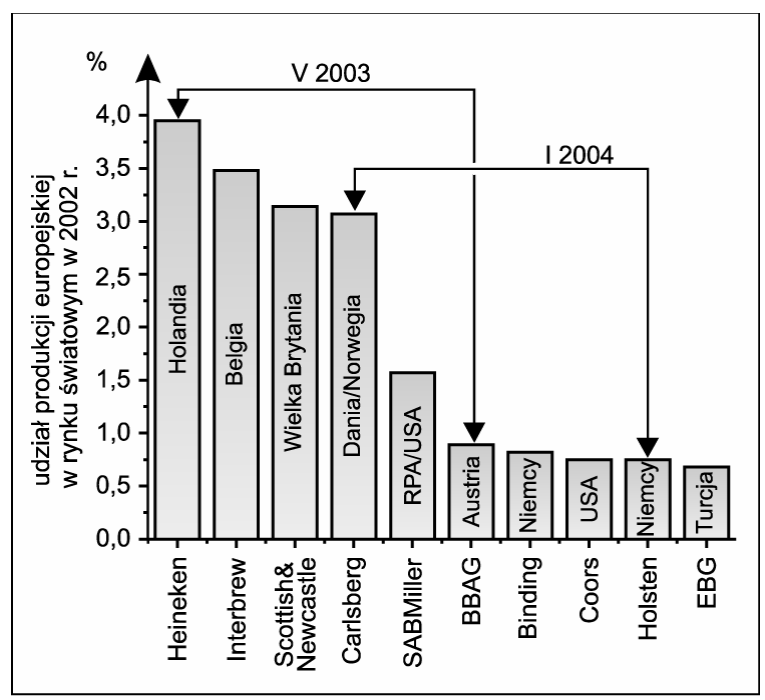

Ryc. 4. Europejski rynek piwa w latach 2002-2004

Źródło: opracowanie własne na podstawie Efes Beverage Group... i in.

Ostatecznie jednak przyjęto ostatni rok, dla którego autor posiadał dane przynajmniej z dwóch różnych źródeł, czyli 2002 (ryc. 4). Należy jednak pamiętać, że od końca roku 2002 na rynku piwowarskim Europy zaszły kolejne zmiany, wśród których jako najważniejsze 
wymienić należy przejęcie przez Heinekena w 2003 r. austriackiej grupy piwowarskiej BBAG/Brau Union (1,9 mld €), przejęcie przez Carlsberga (2004 r.) dziewiątej na liście największych producentów piwa w Europie Holsten Gruppe (1,065 mln €). Umowę podpisano 20 stycznia 2004 r., pod warunkiem sprzedaży browarów w Duisburgu i Lich na rzecz Bittburger Group. Warto zwrócić uwagę, że w większości przypadków wymienione powyżej fuzje powodowały zagrożenie monopolizacją lub co najmniej duopolizacją rynku piwa w wielu krajach europejskich (tab. 2, ryc. 5). Wielkość rynku piwa, jaki mógłby zostać opanowany w wyniku fuzji zaszłych w latach 1990-2003 w przypadku braku uruchomienia procedur antymonopolowych, był różny i wahał się od ok. 35\% do ponad 70\%. Ponadto widać dość wyraźnie stosunkowo oczywistą zależność, polegającą na tym, że im większy jest rynek piwa danego państwa, tym szansa na przejęcie jego bezwzględnej większości niższa (ryc. 5).

Tabela 2. Wybrane przykłady zakupów i przejęć w branży piwowarskiej w Europie, będących przedmiotem postępowań antymonopolistycznych

\begin{tabular}{|l|l|l|c|}
\hline \multicolumn{1}{|c|}{ nazwa koncernu } & \multicolumn{1}{|c|}{ firmy zakupionelfuzja } & \multicolumn{1}{c|}{ państwo } & $\%$ rynku \\
\hline \multirow{2}{*}{ Heineken } & Cruzampo & Hiszpania & $34 \%$ \\
\cline { 2 - 4 } & BBAG/Brau Union & Polska & $37 \%$ \\
\hline Scottisch \& Newcastle & Kronenbourg & Francja & $41 \%$ \\
\hline \multirow{4}{*}{ Carlsberg } & \multirow{3}{*}{ fuzja z Orklą } & Norwegia & $61 \%$ \\
\cline { 2 - 4 } & & Szwecja & $57 \%$ \\
\cline { 2 - 4 } & Feldschlossen & Litwa & $72 \%$ \\
\hline SAB & Pilsner Urquell i Radegast & Czechy & $45 \%$ \\
\hline Interbrew & Bass Plc & Wielka Brytania & $38 \%$ \\
\hline
\end{tabular}

Źródło: opracowanie własne na podstawie Cosh, Guest 2001 i in.

Ryc. 5. Wybrane przykłady konsolidacji w przemyśle piwowarskim Europy, będących przedmiotem

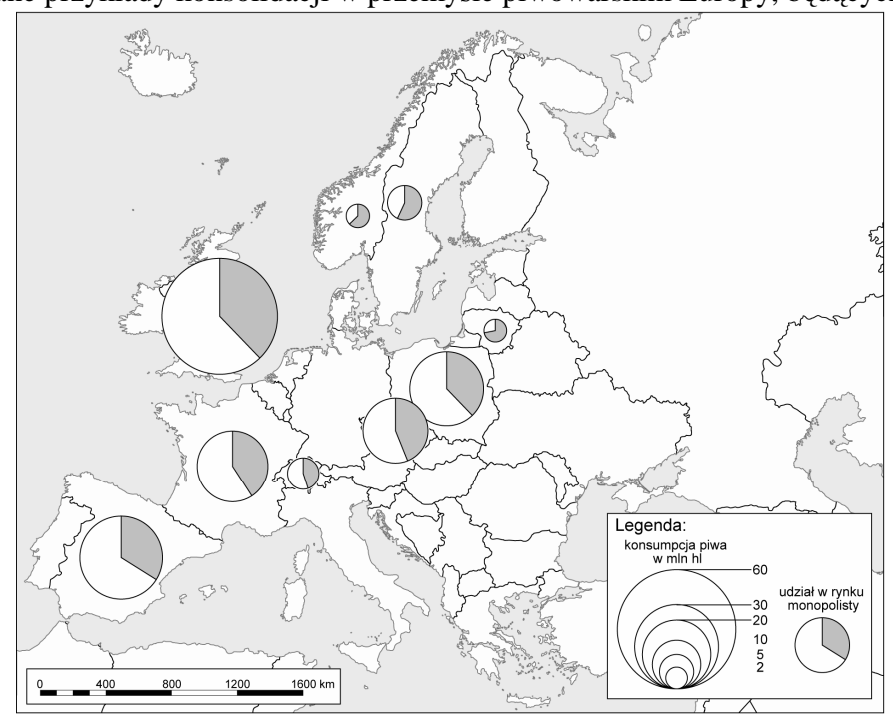

postepowań antymonopolistycznych w Europie w latach 1990-2003

Źródło: opracowanie własne na podstawie tab. 2 i in. 


\section{PERSPEKTYWY}

Skala zachodzących zmian, jak również ich charakter prowadzą do przypuszczenia, że jest bardzo mało prawdopodobne, aby oba omówione procesy nie znajdowały swojego odzwierciedlenia w koncentracji produkcji piwa w poszczególnych krajach Europy. Rozpatrywanie tego zjawiska w skali Europy prowokuje następujące pytania badawcze:

- w jaki sposób omówieni powyżej globalni gracze na rynku piwowarskim Europy zachowują się w jej przestrzeni?

- jakie mogą być tego potencjalne przyczyny?

- czy zachowanie globalnych koncernów piwowarskich w wymiarze przestrzennym różni się, czy też wykazuje więcej podobieństw?

Próba odpowiedzi na powyższe pytania wykracza jednak, głównie ze względu na ograniczenia ilościowe, daleko poza ramy niniejszego opracowania.

\section{Literatura}

Cosh A., Guest P., 2001, Merger Policy in the UK: The Case of the Interbrew - Bass Acquisition. University of Cambridge, The Judge Institute of Management Studies

Efes Brewing Group Analist Meeting-October 2003

Lopes T.S., 2003, Diversification Strategies in the Global Drinks Industry. Said Business School University of Oxford

Pearce R.D., 1993, The growth and evolution of multinational enterprise Edward Elgar, Aldershot

Piwowarstwo europejskie i światowe, 2002, „Przemysł Fermentacyjny i Owocowo-Warzywny”, nr 5, s. 32-34

„Rynki Alkoholowe” roczniki 1998-2003

Dane:

Euromonitor International za Rynkami Alkoholowymi

Ponadto przy opracowaniu korzystano $\mathrm{z}$ danych organizacji Brewers of Europe, raportów rocznych Interbrew, The Coors, EBG oraz SABMiller publikacji Office for Official Publications of the European Communities dotyczących postępowania antymonopolowego w sprawie: Case No COMP/M.2569 - INTERBREW / BECK.S

Skorzystano również bieżących informacji koncernów piwowarskich zamieszczanych na następujących stronach internetowych:

http://www.bbag.com/bbag/home.nsf/framesets/Home

http://www.beerme.com/

http://www.brewersofeurope.org

http://www.carlsberg.com

http://www.efesbev.com/anasayfa.htm

http://www.heinekeninternational.com/

http://www.interbrew.com/index2b.html

http://www.sabmiller.com/

http://www.scottish-newcastle.com/ 